\title{
NEGATIVE TRANSFER OF INDONESIAN COLLOCATIONS INTO ENGLISH AND IMPLICATIONS FOR TEACHING ENGLISH AS A FOREIGN LANGUAGE
}

\author{
Mashadi Said \\ Email: mashadi@staff.gunadarma.ac.id, mashadisaid@yahoo.com \\ Universitas Gunadarma Jakarta \\ Alamat Koresponden: Kompleks Taman Puspa 74. Jln Kol. Pol. Pranoto, Kelapa Dua Cimanggis Depok 16951
}

\begin{abstract}
One of the most challenging problems for EFL students is to be able to express themselves not just grammatically but also acceptably and naturally in English in appropriate contexts. The ability to produce acceptable and natural expressions in English is closely related to the EFL students' competence in collocation-which words go together in normal usage. The present study provides an empirical analysis on negative transfer made by Indonesian EFL students in lexical collocation and recommends practical ways to help students improve their competence in collocation. Data for the study was collected from essays written by 40 EFL university students majoring in English in Indonesia whose native language is Indonesian. The students were asked to write a two- to threepage essay on an assigned topic. Of 445 lexical collocation errors found in the English writing, 321 $(72 \%)$ were negative transfers of Indonesian lexical collocations into English. The findings suggest the necessity of direct teaching of collocations, the use of The Collins WordbanksOnline, and the need to design bilingual collocation dictionaries.
\end{abstract}

\section{Keywords}

Negative Transfer, Lexical Collocation, Indonesian Collocation, Acceptable Collocation

\section{Introduction}

The importance of identifying errors-e.g. negative transfer errors-made by students of English was pointed out by Corder (1978). He argued that systematically analyzing errors made by language students makes it possible to determine areas that need reinforcement in teaching. However, systematic and in-depth analysis of Indonesian EFL students' collocation errors has not been done yet.

A number of studies on collocation errors from other languages have been done. For example, Nesselhauf (2003) analyzed the use of verb-noun collocations such as 'take a break' or 'shake one's head' by advanced German-speaking learners of English in free written production. The result of his analysis is that the learners' L1 has a much stronger influence than earlier studies had predicted. Taiwo (2003) conducted research into collocation errors made by secondary school students in Nigeria. The findings were that collocation errors with the highest percentage were those that deal with the syntagmatic pairing of incompatible items-i.e. two immediately cooccurring items-while errors with the lowest percentage were those that deal with the juxtaposition of several items-i.e. more than two items-which do not collocate. Li (2005) conducted research on Taiwanese students and found that the students made both lexical collocation errors, i.e. open-class word with openclass word and grammatical collocation errors, i.e. open-class word with closed-class word, with roughly the same frequency.

However, some studies have found that lexical collocation errors are more frequent than grammatical collocation errors. For example, Wible, et al. (2003) examined error types in the essays submitted through the web-based language learning system, Intelligent Web-based Interactive Language Learning and found that lexical miscollocations are among the most prevalent. Mahmoud (2005), through a systematic and indepth analyses of EFL learners' lexical errors, reported that of 420 collocations found in 42 essays written by Arabic-speaking university students majoring in English, two thirds of these collocations (64\%) were incorrect and $80 \%$ of these were lexical collocation errors. Furthermore, he claims that $61 \%$ of the lexical miscollocations were negative transfer of students' native language (Arabic). Ying (2009) attempted to identify the 
characteristics of collocations and determine the existence of a relationship between collocations and coherence in writing by Chinese EFL students. The result shows that both Chinese non-English and English majors made more lexical collocation errors, i.e. open-class word with open-class word, than grammatical collocation errors, i.e. open-class word with closed-class word.

Two of the very few studies regarding Indonesian students that have been published were conducted by Kweldju (1999) and Moekardi (2002). The study on collocation conducted by Kweldju was aimed at describing the ability of the English department students of Indonesia in collocations. She used a fill-in the blanks test to obtain her data which revealed that the subjects had a low mastery of collocations. Another study was a nonresearch-based analysis by Moekardi (2002) who suggested some possible problems with grammatical and lexical collocations that Indonesian students may encounter. She predicted that there are three main problems that Indonesian EFL students may encounter with lexical collocations. One would be Noun + Verb as in 'make a conclusion' because the students directly transfer Indonesian collocation membuat kesimpulan ( membuat $=$ make and kesimpulan $=$ conclusion $)$. The second possible problem that Indonesian students may encounter is the collocation Adjective + Noun, such as 'thick coffee' as a direct translation of kopi kental in Indonesian (kental = thick and kopi = coffee) . The third possible problem is that of overusing the English adverb 'very' which is equivalent to Indonesian adverb sangat. Many English adverbs that procede adjectives have the same meaning of Indonesian adverb sangat. Students may play safe by avoiding using other adverbs. For example, instead of saying 'These companies are fiecely/keenly competitive with each other', the students may say 'These companies are very competitive with each other.'

The present study, however, attempts to analyze Indonesian EFL students' negative transfer of Indonesian into English based on an empirical study of actual writing samples looking at lexical collocation in particular. The purpose of this study was to identify the kinds of negative transfer of lexical collocations into English produced by Indonesian EFL students and to recommend practical ways to improve students' collocation in English. 


\section{Conclusion}

The result of this study shows that Indonesian EFL students produce negative transfer errors in expressing themselves in English; they directly translate Indonesian collocations into English. The finding confirms and enriches the findings of earlier studies conducted in the area of collocation of foreign language students in general and Indonesian students in particular. The study provides empirical data verifying the belief that collocations constitute a challenging area in learning English as a foreign language. Indeed, the findings support the claim that EFL students make errors when producing collocations in English, especially the lexical combinations (Wible, et.al., 2003; Mahmoud, 2005; Ying, 2009).

The findings imply that direct instruction of collocation is a must. First of all, teachers should make the students aware of the importance of collocation in communication as people usually do not communicate with single words but with a number of collocates. This might be done through 'noticing' and making use of collocation resources, such as Collins WordBanksOnline English Corpus and Google search engine.

This study, however, involved a very limited number of English department students' essays in Indonesia and, as such, this is a limitation that needs to be acknowledged. Further research should pursue the same issue-both lexical and grammatical collocation errors-with a larger number of samples. Furthermore, it is suggested that a more fine-grained analysis of the types of lexical pairs be conducted for further studies and in different types of texts: narrative, argumentative, and expository in different types of contexts, such as academic, journalism, politics, religion. Such research will help document collocations that need to be taught for Indonesian students in particular.

\section{REFERENCES}

Alonso, M. R. 2002. The Role of Transfer in Second Language Acquisition. Vigo: Universidade de Vigo, Servicio de Publicacións.

Bahns, J. and Eldaw, M. 1993. Should We Teach EFL Students Collocations? System, 21, 101-114.

Benson, M., Benson, E., and Ilson, R. 1997. The BBI Combinatory Dictionary of English: A Guide to Word Combinations. John Benjamins, Amsterdam and Philadelphia.

Corder, S. P. 1974. Error Analysis. In J. P. B. Allen and S. Pit Corder (eds.) Techniques in Applied Linguistics (The Edinburgh Course in Applied Linguistics:3). London: Oxford University Press (Language and Language Learning), pp. 122-154.

Corder, S.P. 1978. Error Analysis and Interlanguage. London: O.U.P.

Fellbaum, C. (ed.). 2007. Idioms and Collocation: Corpus Based Linguistic and Lexicographic Studies. London: Continuum.

Gitsaki, C. 1999. Second Language Lexical Acquisition: A study of The Development of Collocational Knowledge. San Francisco: International Scholars Publications.

Hill, J. 2000. Revising Priorities: From Grammatical Failure to Collocational Success. In Lewis, M. (Ed.) Teaching collocation, 47-69. Croatia: Heinle.

Hsu, T.J. 2008. Lexical Collocations and Their Relation to Speaking Proficiency of College EFL Learners in Taiwan. Asian EFL Journal, 10(1), Retrieved from http://www.asian-efl-journal.com/

Hunston, S. 2002. Corpora in Applied Linguistics. Cambidge: Cambidge University Press.

Kweldju, S. 1999. English Department Students' Collocation Abilities. Teflin Journal. 10, (2).

Larson, L. M. 1998. Meaning-Based Translation: A Guide to Cross Language Equivalence (2 ${ }^{\text {nd }}$ Ed.). Lanham: University Press of America. 
Laufer, B. \& Girsai, N. 2008. Form-Focused Instruction in Second Language Vocabulary Learning: A Case for Contrastive Analysis and Translation. Applied Linguistics, 29 (4), 694-716.

Lea, D. (Ed.) 2002. Oxford Collocations Dictionary for Students of English. Oxford: Oxford University Press.

Lewis, M. 2000. Language in The Lexical Approach. In Lewis, M. (Ed.) Teaching Collocation, 126-154. Croatia: Heinle.

Lewis, M. 2002. Implementing The Lexical Approach: Putting Theory Into Practice. Heinle, Thomson Corporation.

Li, C. 2005. A study of Collocational Error Types in ESL/EFL College Learners' Writing. M.A. Thesis. Ming Chuan University.

MacCarthy, M. 1984. A New Look at Vocabulary in EFL. Applied Linguistics, 5(1), 12-22.

Mahmoud, A. 2005. Collocation Errors Made by Arab Learners of English. Asian EFL Journal, 5(2). Retrieved 12/01/09 from http://www.asian-efl-journal.com/

Moekardi, R. R. D. 2000. Grammatical and Lexical English Collocations: Some Possible Problems to Indonesian Students of English. Humaniora. 14, 53-62.

Nesselhauf, N. 2003. The Use of Collocations by Advanced Learners of English and Some Implications for Teaching. Applied Linguistics, 24, 223-242.

Roberts, M. A. 1995. Awareness and The Afficacy of Error Correction. In R. Schmidt (Ed.) Attention \& Awareness In Foreign Language Learning, (pp. 163-177), Honolulu: University of Hawai'I Press.

Schmitt. 2000. Vocabulary in language teaching. Cambridge: Cambridge University Press.

Selinker, L. 1974. Interlanguage. In Richards, J.C. (ed.) Errors Analysis: Perspectives In Second Language Acquisition, (pp. 31-54), London: Longman.

Selinker, L. 1992. Rediscovering interlanguage. New York: Longman.

Shei, C.C. 2008. Discovering The Hidden Treasure on The Internet: Using Google to Uncover The Veil of Phraseology. Computer Assisted Language Learning, 21(1), 67-85.

Sinclair, J. M., Jones, S, \& Daley, R. 2004. English Collocation Studies. The Osti Report, London: Continuum.

Taiwo, R. 2003. Collocational Errors in The Written English of Senior Secondary School Pupils in Six YorubaSpeaking States in Nigeria. PhD Dissertation, Obafemi Awolowo University. Retrieved October 26, 2009 from http://linguistlist.org/.

The Collins WordbanksOnline. [On-line]. Available: http://www.collins.co.uk/Corpus/CorpusSearch.aspx.

White, L., Spada, N., Lightbown, P.M. \& Ranta, L. 1991. Input Enhancement and L2 Question Formation. Applied Linguistics. 12(4), 416-432.

Wible, Kuo, Tsao, Liu, and Lin. 2003. Bootstrapping in a Language Learning Environment. Journal of Computer Assisted Learning, 19, 90-102.

Willis, J., \& Willis, D. 1996. Consciousness-Raising Activities. In J. Willis \& D. Willis (Eds.), Challenge and Change in Language Teaching, (pp. 63-76). Oxford: Heinemann.

Woolard, G. 2000. Collocation-Encouraging Learner Independence. In M. Lewis (Ed.) Teaching Collocation. Further Developments in Lexical Approach. London: Language Teaching Publication.

Wouden, T. 1997. Negative Contexts: Collocation, Polarity and Multiple Negations. New York: Routledge.

Ying, S. 2009. Study on Collocations in English Writing by Chinese Students. Sino-US English Teaching, 6, 25-30. 